\title{
A MALANDRAGEM DE RITA BAIANA: A CONSTRUÇÃO DO EROTISMO E DA VOLUBILIDADE DA PERSONAGEM E AS RAÍZES DA HERANÇA ESCRAVISTA
}

\author{
RITA BAIANA'A MALANDRAGEM: THE DEVELOPMENT OF THE \\ CHARACTER'S EROTISM AND VOLUBILITY AND THE ROOTS OF SLAVERY \\ LEGACY
}

\author{
Recebido: 15/06/2020 | Aprovado: 05/06/2020 | Publicado: 10/07/2020 \\ DOI: https://doi.org/10.18817/rlj.v4i1.2244
}

\author{
Elisa Hübner Alves ${ }^{1}$ \\ Orcid ID: https://orcid.org/0000-0001-5847-7838
}

\begin{abstract}
Resumo: O propósito deste artigo é analisar a trajetória da personagem Rita Baiana em O Cortiço (1890), em especial os pontos que a aproximam da figura do malandro na literatura brasileira. Partindo do perfil traçado por Candido (1970) em Dialética da malandragem e das modulações a esse perfil, propostas por Otsuka (2007), é possível observar que à malandragem, como fenômeno social provocado pelo sistema escravista, acrescenta-se o fator do erotismo quando pensamos nas personagens femininas. Visto isso, enxergar Rita Baiana como "malandra" é também notar seu lugar entre as outras mulheres da narrativa e como a voz do narrador é marcada pela ambivalência do racismo e do desejo ao construir a personagem.
\end{abstract}

Palavras-chave: Rita Baiana. Malandragem. Erotização. Escravidão. O Cortiço.

Abstract: The article aims to analyze Rita Baiana's character development in O Cortiço (1890), especially regarding the common features with the "malandro" figure in brazilian literature. Based on the profile set by Candido (1970) in Dialética da malandragem and the modulations to this profile, presented by Otsuka (2007), it is possible to perceive "malandragem" as a social phenomenom triggered by slavery's system, and also adds to an eroticizing factor when related to the female characters. Thus perceiving Rita Baiana as a "malandra" is noticing her role among other women in the narrative and how the narrator's voice denotes an ambivalence between racism and desire in the character's development.

Keywords: Rita Baiana. Malandragem. Erotism. Slavery. O Cortiço.

\section{Introdução}

Retomando o caminho feito por Candido (1970) sobre as Memórias de um sargento de milícias (1854), o protagonista Leonardinho é a representação do malandro principalmente pela ociosidade, pela aversão ao trabalho e pelo gosto de causar confusão. Pataca Filho é um jovem "sem ofício nem benefício", que se deixa levar pelo destino por ter padrinhos que podem auxiliá-lo quando preciso.

\footnotetext{
1 Licenciada em Letras na Universidade Federal do Rio Grande do Sul (UFRGS). Mestranda na linha de pesquisa Literatura, Sociedade e História da Literatura na Universidade Federal do Rio Grande do Sul (UFRGS) e bolsista CAPES. Experiência com pesquisa em Literatura Brasileira. Email: elisa_hubner@hotmail.com
} 
Ele não se dignifica pelo trabalho, mas sai vitorioso na narrativa a partir dos esforços alheios, que permitem que ele seja malandro.

Avançando no debate, Otsuka (2007) afirma que o romance de Almeida é articulado pelas rixas entre os personagens, numa forma de "compensação imaginária" (p. 118), anseio pela sensação de superioridade entre membros das camadas intermediárias. As rixas surgem como reflexo da sociedade escravista, que restringia as possibilidades de trabalho e a ascensão do homem livre pobre, promovendo o surgimento da figura do malandro como alternativa:

Nessas condições, os homens livres pobres só encontravam maiores chances de obter os meios de sobrevivência através de mecanismos específicos, diferentes do trabalho assalariado, já que não encontravam lugar na esfera da produção, ocupada pelo trabalho escravo; daí a vigência do favor e da malandragem - o que tinha consequências inclusive no âmbito dos homens livres com ofícios e ocupações regulares. (OTSUKA, 2007, p. 118)

O processo social da malandragem surge como alternativa à falta de trabalho formal e como reação ao sistema escravista, causando rixas internas entre os indivíduos da mesma camada social. No romance de Almeida, a malandragem é representada por Leonardinho, pertencente ao que se poderia chamar à época de proto-classe média branca, à "pequena burguesia" (CANDIDO, 1970, p. 74) do romance.

Já em $O$ Cortiço, publicado três décadas após a obra de Almeida, encontramos Rita Baiana, personagem que não é apadrinhada. Rita, como Leonardinho, é retratada com "o defeito da vadiagem" (AZEVEDO, [s/d], p. 19)2, mas sua liberdade é mais restrita, de modo que ela não transita entre as esferas da ordem e da desordem - nem ela nem os outros habitantes pobres do cortiço, como Firmo, Jerônimo, Piedade, Leocádia.

O narrador descreve Rita Baiana duas vezes usando a frase "volúvel como toda mestiça" (p.32 e p.112). Na primeira vez que se refere à relação dela com Firmo, demonstra que Rita é instável e ocasionalmente tem outros amantes. Já no fim do romance, o narrador repete o dito, referindo-se ao encontro de Rita e Piedade, a antiga esposa de Jerônimo, da qual a baiana parece não ter rancor,

\footnotetext{
${ }^{2}$ O romance de Almeida está disponível pelo domínio público, mas no arquivo digital não consta a data de publicação.
} 
mesmo após o enfrentamento agressivo das duas. A repetição do trecho reforça a noção de ambiguidade na personagem; não se sabe o quanto vão durar suas paixões, suas mágoas.

A mulata, afinal, na sua representação da nacionalidade brasileira, atravessa o romance como um signo que comporta valores contraditórios, de perdas e ganhos, dor e prazer, beleza e horrorespécie de Macunaíma de saias, heroína cujo único caráter é não ter um caráter que se possa definir com precisão. (MENDES, 2003, p.25)

Mendes relaciona a personagem com a nação brasileira e sua relação com Jerônimo como um "projeto de nação e união", cujas disputas são "resolvidas" com a conciliação do ato sexual. No entanto, se há malandragem em Rita Baiana, não é a mesma de Macunaíma; seu apreço pela comunidade e o auxílio com os outros moradores a afastam do personagem violento. A hipótese da malandra se reflete no seu caráter flexível - não na falta dele - e no erotismo, que encontra raízes históricas no sistema escravista.

No romance de Aluisio Azevedo, o erotismo da mulher negra - no romance, Rita é chamada de mulata ou mestiça - se desenvolve através de um tom animalizado, característico do naturalismo. O narrador do romance ilustra na personagem o que na época era considerado como "meneios da mestiça (...), cheios de uma graça irresistível, simples, primitiva" (AZEVEDO, [s/d], p.38) ${ }^{3}$, preconceitos enraizados na cultura brasileira.

Gilberto Freyre (2003), em Casa-grande \& Senzala, defende que esse "erotismo primitivo" da mulher negra é atribuído a ela injustamente. O autor reconstrói os aspectos sociais e históricos que acusam a escrava de "depravação sexual", revelando tratar-se, na verdade, do poder autoritário dos senhores sobre as escravas. Ele discorda de críticos que acreditavam na "superexcitação" anormal da mulata (FREYRE, 2003, p.425), e mostra que tanto os herdeiros quanto os senhores de engenho tinham posse sobre o corpo da escrava, que não tinha escolha a não ser obedecer aos escravistas ${ }^{4}$.

\footnotetext{
${ }^{3} \mathrm{O}$ romance de Azevedo também está disponível em domínio público, sem a data de publicação no arquivo digital.

${ }^{4}$ A obra de Freyre é publicada originalmente em 1933. Nela, o capítulo estudado "O escravo na vida sexual e de família do brasileiro" não define como estupro a ação dos senhores de engenho, mas vale aqui o comentário.
} 
A proposta de analisar a malandragem de Rita Baiana perpassa a questão da "predisposição" da mulata à sensualidade, com o fundo histórico levantado por Freyre (2003) e o surgimento da malandragem sintetizado nos textos de Candido (1970) e Otsuka (2007). A relação perversa entre proprietário e escrava traz o fator da objetificação da mulher negra que, por hipótese, constitui parte do processo histórico da malandragem na personagem feminina.

\section{Os primeiros malandros}

Em Dialética da malandragem (1970), Antonio Candido analisa Leonardinho Pataca, o primeiro malandro da literatura brasileira, descrevendo sua "origem humilde", irregular e largada no mundo (p.69). Leonardinho é indivíduo que vive como títere, como o crítico aponta, levado pela ocasião às suas aventuras e normalmente auxiliado por agentes externos (como o padrinho, a madrinha, D. Maria).

Apesar dos esforços dos padrinhos, Leonardo segue seus impulsos, deixando claro que sua "realidade interior é mais importante do que o mundo" (DAMATTA, 1997, p. 265), característica vital do malandro, agindo não a partir de normas sociais, mas sim de seus próprios interesses. Supostamente, é possível levar em conta a existência de dois outros malandros na narrativa: Vidinha e Chico-Juca, também ociosos e astutos, mas que estão mais sujeitos às normas. Há um limite para eles maior do que para Leonardinho, devido à falta de apadrinhamento e de heranças - que são benefício exclusivo da elite branca, como a herança que o padrinho arranjara, fruto do tráfico de escravos.

Chico-Juca é personagem secundário no romance, contratado por Leonardo Pai para provocar uma briga e chamar a atenção do major Vidigal. Ele é "a personificação da desavença cotidiana" (OTSUKA, 2007, p.110), o malandro valentão, atrevido. No entanto, acompanhando o tom da narrativa, até a violência de Chico é cômica, afetada: “(...) arrancando-Ihe a viola da mão, bateu-lhe com ela em cheio sobre a cabeça" (ALMEIDA, [s/d], p. 40). Após o ocorrido, a polícia aparece e controla a confusão que ele causara, e Juca foge para não ser preso.

Encontramos o eco de Chico-Juca na figura de Firmo do Cortiço, malandro de navalha, personagem que "não tinha músculos, tinha nervos" 
(AZEVEDO, [s/d], p.32). A violência de Juca, apesar de fazer parte da esfera da desordem, não choca o leitor, apesar do ofício considerado desonesto. Firmo carrega com ele navalha e um porrete, e durante a narrativa provoca um ferimento grave no rival Jerônimo, fugindo da confusão logo em seguida para não ser preso nem agredido por outros moradores do cortiço.

Enquanto Chico e Firmo são malandros fugitivos, a relação de Leonardo com a polícia é um tanto diferente. O major Vidigal, a figura da ordem, persegue o malandro somente pelo crime da vadiagem - o enfrentamento de Leonardo com os primos de Vidinha não chama a atenção da polícia, como a briga de Firmo ou a de Juca - a aparição da ordem é quase instantânea.

Vidigal fracassa várias vezes e se sente humilhado, o que resulta na compreensão do protagonista não como um "criminoso", mas sim como uma afronta: "o desejo de vingança pessoal do major, (...) acaba se sobrepondo à incumbência de manutenção da ordem" (OTSUKA, 2007, p. 109). Leonardinho é a pedra no sapato de Vidigal, que leva o insulto pessoal ao âmbito da esfera pública. O problema é resolvido a partir da lógica do favor, por intermédio da comadre e de D. Maria, que convencem a antiga amante do major a voltar para ele. Ao final do romance, o favor garante a Leonardinho não só a liberdade como uma promoção na carreira, de granadeiro a sargento. Vidigal esquece a antiga rixa com Leonardo, que acaba se estabelecendo na ordem vigente a partir do "poder efetivo" (OTSUKA, 2007, p. 118) da propriedade: agora ele tem um cargo oficial, um casamento e mais de uma herança.

A lógica do favor e as rixas estabelecem relação importante com a malandragem. A partir da rixa, a esfera privada e a pública se confundem, além de causar nos indivíduos um sentimento de superioridade uns sobre os outros (OTSUKA, 2007). O favor, por sua vez, torna as regras e condutas sociais mais "flexíveis", o que permite que Leonardo se livre da prisão, mas a possibilidade não se estende a Juca ou Vidinha, por estarem numa camada social mais baixa, em núcleo marginalizado.

Leonardo, durante o decorrer da narrativa, provocou e tripudiou a todos, alcançando uma "compensação imaginária" pelo sentimento de superioridade (OTSUKA, 2007, p. 122) da rixa. Quando o protagonista estabelece sua relação com uma instituição, isto é, a polícia, não há mais motivo para rixas, pois de fato 
ele está acima dos outros. Não só acima, como agora Leonardinho é parte da ordem que prende malandros, e sua primeira ação como granadeiro é prender o toma-largura, pretendente de Vidinha.

Nesse sentido, o eventual triunfo (pessoal) do pobre não deixa de ser também o seu fracasso (no plano coletivo), pois a luta pela sobrevivência acaba por contribuir para a reprodução da ordem social que o oprime. Assim, a rixa revela na malandragem a sua dimensão sombria. (OTSUKA, 2007, p.122)

É possível afirmar que Leonardo triunfa ao final da narrativa. Os supostos malandros - Chico-Juca e Vidinha - continuam cada um onde estavam, porém ainda mais afastados dele. Chico é um profissional da rixa, que tem de permanecer longe da polícia. Vidinha, por sua vez, só pode ascender pelo casamento, mas é tida como a mulher que "só se pode amar" (CANDIDO, 1970, p.79), exclusivamente sem o dever do matrimônio. Sendo assim, se torna inviável a ela ter um "eventual triunfo" como Leonardinho, pois concorre com Luisinha, jovem branca de família abastada.

Para os leitores de Almeida, Leonardinho jamais poderia permanecer com Vidinha, reflexo do tom moralista do narrador, como na afirmativa: "Com os emigrados de Portugal veio também para o Brasil a praga dos ciganos. Gente ociosa e de poucos escrúpulos" (ALMEIDA, [s/d], p.15). Nem a fala do narrador nem os acontecimentos da narrativa dão abertura a outras impressões sobre os ciganos.

Há na personagem Vidinha um paralelo importante com Rita Baiana, de Aluisio. A cigana, como Rita, encanta e provoca o futuro amante, que permanece com ela na chamada "esfera da desordem". No caso de Jerônimo, Rita o transforma até que ele se torne o oposto do que era: antes um trabalhador responsável, saudoso de sua terra natal, depois da baiana um "vadio brasileiro", malandro de navalha que comete até um assassinato. Quanto a Leonardo, ao se apaixonar por Vidinha ele não muda de caráter, mas "se mete nas encrencas mais sérias e pitorescas, como que libertado dos projetos respeitáveis que 0 padrinho e a madrinha tinham traçado para a sua vida." (CANDIDO, 1970, p.79).

Rita Baiana é, assim como Vidinha, tida como a responsável por "desvirtuar" Jerônimo, contrário aos vícios ou exageros. A força da baiana é muito 
mais intensa do que a personagem das Memórias, até porque ela é a amante de Jerônimo ao fim da narrativa, não a esposa Piedade; o triunfo da mulher brasileira sobre a mulher portuguesa destrói Piedade, de forma que é possível discordar do tom elogioso de Mendes (2003), quando este afirma que as imagens brasileiras evocadas pela "paixão de Jerônimo por Rita, apontam para uma avaliação essencialmente positiva e otimista do país" (p.25).

No Cortiço, a sensualidade da baiana é ao mesmo tempo encanto e maldição, "mulher por quem todos têm algum tipo de fascínio" (CERQUEIRA, 2010, p.140):

O chorado arrastava-os a todos, despoticamente, desesperando aos que não sabiam dançar. Mas, ninguém como a Rita; só ela, só aquele demônio, tinha o mágico segredo daqueles movimentos de cobra amaldiçoada; aqueles requebros que não podiam ser sem o cheiro que a mulata soltava de si e sem aquela voz doce, quebrada, harmoniosa, arrogante, meiga e suplicante.

E Jerônimo via e escutava, sentindo ir-se-lhe toda a alma pelos olhos enamorados. (AZEVEDO, [s/d], p.39)

O romance de Azevedo constrói na personagem um erotismo a partir da hiperssexualização, na qual Rita é chamada de "demônio" de forma sensual: o insulto na forma de elogio, o racismo pelo viés do desejo. Ao analisarmos a malandragem a partir da herança escravista, é importante frisar que, para a mulher negra, há o peso do que se acreditava ser uma "predisposição" à depravação sexual (FREYRE, 2003, p.398), em evidência no trecho de Aluisio.

Na trajetória de Rita Baiana, é possível observar como a objetificação da mulher negra ocorre através da voz do narrador naturalista. Como Araújo (2011) afirma, O Cortiço "avalia negativamente a herança racial brasileira" (ARAÚJO, 2011, p.123), de forma que é possível perceber o tratamento racista, muito mais acentuado do que em Vidinha - não que Almeida esteja isento dele. A partir da noção de malandragem aplicada a Leonardinho e Vidinha, é possível perceber os limites nos desfechos de cada um, a diferença do olhar do narrador sobre eles e a ausência/presença da erotização.

\section{O casamento, a malandragem e o erotismo da mulher negra}


O cortiço de Aluisio de Azevedo é publicado em 1890, romance que trata de um amplo painel de personagens, focalizando alternadamente em núcleos dentro e fora do cortiço São Romão. Figura importante no decorrer do enredo, Rita Baiana é aquela que move a comunidade voluntariamente ou a partir da sua força espontânea: "uma vez que todos que a cercam se voltam para ela e são naturalmente envolvidos e seduzidos pelos seus movimentos, pelos seus requebros" (CERQUEIRA, 2010, p.146).

No seu retorno ao cortiço após uma ausência de três meses, a baiana cumprimenta a todos com desenvoltura, faz um gracejo ou um comentário pessoal que mostram que ela se recorda de cada um deles. Rita é parte do conjunto de moradores e oferece auxílio diversas vezes: comida ao velho Libório, estadia para Marciana ou Leocádia, conselhos para Albino. Diferente de Leonardinho e Macunaíma, Rita Baiana é malandra que encontra na comunidade uma forma de defesa, de troca. "Acudiu quase todo o cortiço para recebê-la. Choveram abraços e as chuvas do bom acolhimento". (AZEVEDO, [s/d], p. 29). Há uma relação solidária dentro do romance que, por interesse ou necessidade, difere daquela encontrada nas Memórias. Rita tem liberdades que outros personagens não têm: ela zomba do militar fardado, de Dona Isabel, da Bruxa, sempre com uma gargalhada, uma intimidade de quem acompanha o que acontece: "E tinha uma frase para cada um que se aproximasse." (AZEVEDO, [s/d], p.30)

Na primeira festa que a baiana promove no cortiço, ela recebe "ajudantes gratuitos" (p.31) para limpar a casa e cozinhar. Convida outros moradores para a janta: "pobre gente miserável, que mal podia matar a fome com o que ganhava" (p.35), mostrando que, enquanto houvesse recursos, Rita não poupava em gastar com os outros. Tempos depois, quando ela acolhe a mulher do ferreiro, afirma: "Ah, meu amigo, neste mundo hoje por mim, amanha por ti!..." (p.49), de forma que a camaradagem se estabelece no cortiço entre os brasileiros, às vezes agregando os portugueses, quando não há conflito entre os dois lados.

À Rita não faltam amigos nem pretendentes, apesar de declarar-se avessa ao casamento. Rita Baiana não parece ter problemas com a monogamia que o matrimônio demanda, mas sim com as regras que seriam impostas pelo marido, o controle sobre seus bens materiais e a ameaça da agressão física. Rita 
evidencia tais opiniões durante vários momentos na narrativa, entre eles quando fala da prostituta Léonie:

(...) seja assim ou assado, a verdade é que ela [Léonie] passa muito bem de boca e nada lhe falta: sua boa casa; seu bom carro para passear à tarde; teatro toda a noite; bailes quando quer e, aos domingos, corridas, regatas, pagodes fora da cidade e dinheirama grossa para gastar à farta! [grifo meu] Enfim, só o que afianço é que esta não está sujeita, como a Leocádia e outras, a pontapés e cachações de um bruto de marido! É dona das suas ações! livre como o lindo amor! Senhora do seu corpinho, que ela só entrega a quem muito bem Ihe der na veneta! (AZEVEDO, [s/d], p. 55-56)

A baiana elogia Léonie por não se sujeitar à violência de um marido, e exemplifica a partir da cena que ocorrera com Leocádia, agredida e expulsa de casa por adultério. Além disso, Rita exalta o dinheiro e as posses da prostituta, grifadas no trecho, o que indica também que ela dava valor à autonomia financeira e à autossuficiência.

No romance de Azevedo o casamento não é garantia de desfecho positivo, como indicam as relações entre Miranda e d. Estela: ambos não se suportam e ela é adúltera; Leocádia e Bruno, já mencionados; Jerônimo e Piedade, ela é abandonada e tem de sustentar a filha sozinha. As outras personagens são viúvas ou separadas, como Dona Isabel, Marciana, das Dores e Leandra (Machona). O único matrimônio que aparenta ter aspecto mais harmônico é o de Alexandre e Augusta.

À exceção do adultério recorrente nos outros casais, o casamento de Augusta não apresenta o problema da infidelidade. Ela religiosa, ele militar, ambos são brasileiros crédulos do funcionamento da ordem social, sem desconfiança nas autoridades ou nos que estão no seu convívio. A felicidade do casal parece vir de uma falta de consciência de realidade, que se faz bem ao casamento, não os isenta de sofrerem desgraças, como a morte de uma das filhas, nem de serem enganados. Sua filha Jujú, por exemplo, vive com a prostituta Léonie e se veste como ela; os pais festejam e exaltam a cocote, ao passo que o narrador descreve a reação de Alexandre: "um ar condolente e estúpido de um profundo reconhecimento por aquela fortuna, que Deus lhe dera à filha, enviando-Ihe dos céus o ideal das madrinhas." (p. 55). Há aqui um juízo de 
valor impresso na fala do narrador, ao caracterizar o reconhecimento de Alexandre como "estúpido", e revelando que a prostituta, provavelmente, tinha segundas intenções com a jovem, assim como demonstra depois com Pombinha.

Rita Baiana não tem o apreço do casal pelas instituições. Na cena que Rita volta ao cortiço, ela zomba do militar fardado com uma continência e uma gargalhada (p.30) e, como é sabido, desdenha o casamento. Há uma astúcia na personagem que se mostra pela desconfiança, como a reação de Rita ao ver Léonie: há também um tipo de reverência ao entregar o ramalhete de flores à prostituta, mas ao mesmo tempo, o narrador mostra que esta "não se iludia com a posição da loureira" (AZEVEDO, [s/d], p. 55). Tal afirmação tem caráter ambíguo, pois não se sabe se a referência é à influência de Léonie na comunidade ou à bondade que ela aparentava ter.

A instituição do casamento em $O$ Cortiço difere bastante daquela encontrada nas Memórias. O matrimônio não garante a felicidade, e Rita Baiana parece estar plenamente consciente disso pela maior parte da narrativa. É possível fazer um paralelo com Damatta (1997), que define como característica do malandro ser um "relativizador das leis, regulamentos, códigos e moralidades que sufocam o indivíduo sem berço no jugo do trabalho e servem para perpetuar as injustiças sociais." (p.276). Rita percebe as desvantagens do casamento; decide então fazê-lo temporário, em uniões informais e que dependem de sua satisfação.

É possível dizer que uma vantagem dessas uniões é a de garantir a ela estabilidade financeira. Se Rita não trabalha de modo assíduo, como a narrativa mostra, é difícil imaginar de que outra maneira a baiana seria capaz de manter o aluguel de um cômodo desocupado no cortiço, de festejar com os vizinhos frequentemente e de ficar fora "na folia" por três meses. A narrativa indica também que era comum que ela fosse embora: "Pode haver o serviço que houver, aparecendo pagode, vai tudo pro lado!” (AZEVEDO, [s/d], p.19). Além disso, não dá sinais que nada lhe falte, pois sempre há quem "puxe por ela".

Uma das formas que Rita encontra de se manter financeiramente é a partir dos seus amantes, mas diferente de uma união formal, ela pode sair da relação quando esta a prejudica ou apenas perde a intensidade - ainda que não esteja livre, como outras mulheres, de agressões e ameaças. No romance de 
Aluisio, há um tom moralista que determina o livre arbítrio de Rita como "poucavergonha", ou ainda como "fogo no rabo" (p.18), já que ela é "volúvel como toda mestiça" (p.23).

O romance com Firmo é algo descontínuo, interrompido por ciúmes, brigas, porém acaba de vez quando ela encontra Jerônimo. Rita declara que a conexão com Firmo durou apenas pelo "instinto luxurioso e canalha que predominava em ambos", mas que depois caíram no hábito. (p.93) Sabendo disso, Jerônimo se sente temeroso com a possibilidade de perdê-la:

Rita era desperdiçada e amiga de gastar à larga; não podia passar sem uns tantos regalos de barriga e gostava de fazer presentes. Ele, receoso de contrariá-la e quebrar o ovo da sua paz, até ai tão completo com respeito à baiana, subordinava-se calado e afetando até satisfação; no intimo, porém, o infeliz sofria deveras. (AZEVEDO, [s/d], p.111)

O trecho retoma novamente o gosto de Rita por comprar e esbanjar, o que representa um problema para Jerônimo, já que os seus "quinhentos mil réis para as primeiras despesas" (p.95) estavam acabando. Sua antiga esposa Piedade pedira dinheiro para o colégio da filha, mas o português, apesar da culpa, escolhe não bancar a educação da menina, continuando a sustentar Rita e satisfazer seus caprichos.

Do outro lado do envolvimento de Rita e Jerônimo está a desgraça de Piedade. Quando ela vai ao hospital visita-lo, após a luta com Firmo, o marido demonstra total indiferença: "sem uma palavra de ternura para ela, deixando até perceber a sua impaciência para ouvir falar da outra, daquela maldita mulata dos diabos" (AZEVEDO, [s/d], p.75). O descaso com Piedade se agrava até resultar na infidelidade e, por fim, no abandono. A rivalidade entre as duas se torna destrutiva para a portuguesa, e o narrador faz uma comparação evidente. Logo após Jerônimo negar o dinheiro à filha, ele e Rita Baiana voltam à normalidade e desconsideram a visita da portuguesa:

E abraçaram-se com ímpeto, como se o breve tempo roubado pelas visitas fosse uma interrupção nos seus amores.

Lá fora, junto ao portão da estalagem, Piedade, com o rosto escondido no ombro da filha, esperava que as lágrimas cedessem um pouco, para as duas seguirem o seu destino de enxotadas. (AZEVEDO, [s/d], p.113) 
O triunfo de Rita Baiana no romance é construído como causa da degradação de Piedade. Quando Jerônimo observa a baiana dançar, ele cai num torpor de admiração, sobre o qual o narrador declara: "Isto era o que Jerônimo sentia, mas o que o tonto não podia conceber. (...) E deixava-se [grifo meu] ficar, olhando." (AZEVEDO, [s/d], p.39). A atração de Jerônimo por Rita revela-se a partir da "fraqueza" do português, que cai pelo "feitiço sensual" da baiana. No trecho citado, o uso do verbo "deixava-se" denota ausência de culpa em Jerônimo, pois ele, como "tonto", não consegue resistir aos encantos de Rita.

A voz do narrador, que coloca a personagem como culpada pelo adultério de Jerônimo, guia o leitor ao declarar que Rita está "consciente" de seu feitiço sobre o português. Rita Baiana é capaz de fazer "os homens estremecerem e sentirem imenso desejo de possuí-la, de fazê-la sua amante, sua fêmea." (CERQUEIRA, p.140), em contraste a Jerônimo, "pateta, esquecido de tudo; babão" (p.50).

Há uma vaidade de Rita em conquistar Jerônimo, que parece evocar o sentimento de superioridade da malandragem (OTSUKA, 2007). Ele se revela na satisfação pessoal de Rita Baiana pelo desejo que provoca; Rita aprecia a disputa dos seus dois amantes, Jerônimo e Firmo: "aqueles dois homens a se baterem por causa dela; um ligeiro sorriso encrespava-lhe os lábios" (p.66).

Não apenas Jerônimo, como o próprio narrador - nada impessoal enxerga Rita Baiana com desejo, de forma que este transparece na narrativa:

\begin{abstract}
E toda ela respirava o asseio das brasileiras e um odor sensual de trevos e plantas aromáticas. Irrequieta, saracoteando o atrevido e rijo quadril baiano, respondia para a direita e para a esquerda, pondo à mostra um fio de dentes claros e brilhantes que enriqueciam a sua fisionomia com um realce fascinador. (AZEVEDO, [s/d], p.29)
\end{abstract}

Ao longo do romance, essa fascinação aproxima a personagem metaforicamente de uma serpente (CERQUEIRA, 2010, p.140). Enquanto isso, a esposa de Jerônimo é caracterizada como "mulher do trabalho, desprovida de sexualidade" (MENDES, 2003, p.23), revelando que Rita e Piedade apresentam uma oposição não só na esfera do desejo como do trabalho. A dualidade das duas remete a de Vidinha e Luisinha das Memórias, uma atraente e a outra "feia e esquisita" (p.50), ainda que Luisinha seja herdeira e não tenha de trabalhar, como 
Piedade. Jerônimo e Leonardinho se aproximam também, o primeiro "enfeitiçado" pela baiana, o segundo com uma "predisposição hereditária" para desejar ciganas, como Leonardo Pai.

A partir da construção da personagem Rita Baiana, é possível inferir que há uma herança cultural do sistema escravista na erotização da personagem e na rivalidade entre a ela e Piedade. A rivalidade entre as duas mulheres, a negra e a senhora branca, retoma as raízes escravistas da leitura de Freyre (2003). O autor revela como a escrava era responsabilizada e punida pelo adultério do senhor de engenho, muitas vezes maltratada pela senhora da casa, vendida a "velhos libertinos" ou sujeita à mutilação, sendo "o motivo, quase sempre, o ciúme do marido. O rancor sexual. Rivalidade de mulher com mulher." (p. 393).

A comparação segue no capítulo sobre a aparência saudável da negra com a insalubre da branca. A violência do sistema patriarcal e escravista demandava que as senhoras brancas casassem ainda "fisicamente incapazes de ser mães em toda a plenitude. Casadas, sucediam-se nelas os partos." (FREYRE, 2003, p.440). Por conta disso, era comum registrarem-se mortes de parto, abortos, além do desgaste físico e psicológico das sinhás-moças, que ficavam "uns mulambos de gente".

As escravas, de acordo com o crítico, se adaptavam melhor à temperatura dos trópicos (FREYRE, 2003, p.441). Parte da rixa entre as mulheres - a sinhá e a escrava - tratava-se desse contraste com a aparência das negras, com seus "dentes alvos e inteiros", enquanto a maioria das senhoras não tinha dentes saudáveis, "uma das causas principais de ciúme ou rivalidade sexual entre senhoras e mucamas" (FREYRE, 2003, p. 414).

Visto isso, é possível perceber traços da herança escravista na rivalidade e no enfrentamento entre mulheres, a branca e a negra, que tem origem no arbítrio do senhor de engenho. A sensualidade de Rita Baiana, que cativa Jerônimo e Firmo, é capaz de provocar ciúmes intensos, ainda que o motivo do contraste com Piedade seja bem diferente: enquanto as sinhás se desgastavam nos partos, Piedade sofria no trabalho cotidiano. Além disso, vale lembrar que Rita é caracterizada como personagem que trabalha muito pouco, ao contrário das escravas da casa grande. Ainda assim, a rivalidade histórica encontra eco 
nas duas personagens através da aparência, do ciúme e da atenuação de culpa do homem no adultério.

Aluisio constrói seu romance a partir da estética naturalista brasileira, com pressupostos como o "cientificismo" e o "determinismo", que carregam valores da sociedade escravista, apesar do autor ser um abolicionista. Entre esses valores, está a "depravação sexual" da mulher negra, explicitada por Freyre (2003): "Ninguém nega que a negra ou a mulata tenha contribuído para a precoce depravação do menino branco da classe senhoril." 5 (p.427). No trecho, percebemos que Freyre evidencia a crença de historiadores e sociólogos sobre a "culpa" da mulher negra na vida sexual do jovem branco. O reflexo do trecho se relaciona a Rita e Jerônimo, "enfeitiçado" pela baiana, sujeito à sua vontade e volubilidade.

A maneira como o narrador do Cortiço descreve Rita, com seus "meneios de mestiça", mostra que o erotismo da baiana não é construído positivamente. De acordo com Candido (1993), a narrativa é caracterizada pela "degradação motivada pela promiscuidade" e "também pelo sexo e a violência." (p.113). A hiperssexualização de Rita Baiana mistura racismo e desejo por parte do narrador, já que ele a rebaixa a partir de julgamentos de valor, como ao chama-la de "demônio" ou ao afirmar que sua dança tinha "movimentos de cobra amaldiçoada", ao mesmo tempo em que deseja a mulher negra: "aqueles requebros que não podiam ser sem o cheiro que a mulata soltava de si e sem aquela voz doce, quebrada, harmoniosa, arrogante, meiga e suplicante." (p.3839).

O narrador se refere a ela com animalidade ao descrevê-la como "pomba no cio" (p.64), e reduz a personagem à condição de "fêmea", seguindo o padrão de degradação da narrativa em que "o homem pode ser confundido com o bicho e tratado de acordo com esta confusão" (CANDIDO, 1993, p.114). O trecho referese à exploração do trabalho, mas pode ser aplicado também à descrição dos impulsos sexuais dos personagens.

\footnotetext{
${ }^{5}$ Nesse capítulo, Freyre defende que a "depravação" ocorre em função do sistema escravista, não se trata de uma "predisposição" da mulher negra, e sim da condição que o escravagismo impõe. $O$ capítulo mostra que havia várias afirmações "científicas" atribuídas à escrava acerca de sua influência na vida sexual.
} 
Rita Baiana transforma Jerônimo, o desvirtua até que se torne brasileiro, como aspecto pejorativo da brasilidade. Antes trabalhador, agora ocioso, adúltero e assassino. A partir da obra de Freyre (2003), que revela as associações incorretas acerca da "depravação sexual" da mulher negra durante a escravidão, e da voz nada impessoal do narrador, que não mascara o desejo e o racismo, é possível perceber o processo histórico da "culpa" da personagem.

A hipótese da malandragem está nas características que a assemelham a Leonardo Filho, como a ociosidade, a simpatia e a astúcia, além de se mover a partir dos próprios interesses, colocando de lado normas sociais como a instituição do casamento - e tornando vantajosa a união temporária. Há diferenças, porém, que estabelecem limites na malandragem de Rita Baiana, como gênero, classe social e etnia, e conferem vantagens históricas a Leonardinho, garantindo que este vire herdeiro, livre de agressões de amantes e de qualquer erotização.

Há uma continuidade da rivalidade histórica no desfecho de Rita, que retoma o conceito de "supremacia qualquer" de Otsuka (2007). A malandra se torna superior por ter amantes à sua escolha, mas a disputa é violenta e traz danos aos envolvidos, como a lesão de Jerônimo, o abandono de Piedade e a morte de Firmo, o que pode indicar na malandra brasileira uma relação direta com os ciúmes e a morte. Seu desfecho individualmente "positivo" ao final da narrativa não garante estabilidade, além de estar suscetível à violência recém-aflorada de Jerônimo e assombrado pela desgraça de Piedade.

\section{Considerações Finais}

O protagonista de Memórias de um sargento de milícias sobe na vida sem esforço, dotado da condição de protegido, de sorte e de simpatia, com a permissão para quase tudo, o que o coloca como figura do "malandro", analisado por Candido (1970) em Dialética da malandragem. Expulso de casa pelo pai após a morte do padrinho, ele anda sem rumo até ouvir gargalhadas (ALMEIDA, [s/d], p.75), encontra um amigo e fica por ali mesmo, com um grupo de ciganos. Como afirma o narrador das Memórias, Leonardo se entrega à "confiança cega no dia de 
amanhã" (p.75), o que é efeito da mocidade e da "predisposição" hereditária de se envolver com uma cigana, assim como Leonardo Pai.

Vidinha, a cigana por quem Leonardinho se apaixona, é também caracterizada como "ociosa", astuta e, por hipótese, se trata de uma malandra como ele, porém o narrador demonstra antipatia com "a praga dos ciganos" (p.15). Seu desfecho não é positivo, uma vez que ela não consegue permanecer na união com Leonardo, enquanto ele ascende socialmente. Visto isso, é possível questionar se o trânsito entre as esferas da ordem e da desordem é viável também para as camadas mais pobres, e como a malandragem aparece para personagens que não sejam apadrinhadas.

A cigana encanta Leonardo, mas não consegue impedir que ele se case. $\mathrm{Na}$ sua relação com Vidinha é possível notarmos um paralelo entre ela e a personagem de $O$ Cortiço, Rita Baiana. Rita é tida como a responsável por "desvirtuar" Jerônimo, trabalhador sério, casado, contrário aos vícios ou exageros, porém ao fim da narrativa ela permanece como amante do português.

O caráter de volubilidade de Rita Baiana fica explícito pelo narrador, além de sua capacidade de "enfeitiçar" os amantes - "objetos de satisfação erótica" (CERQUEIRA, 2010, p. 11). A construção do romance reflete na lubricidade da personagem um fundo histórico, herança da escravidão na representação da mulher negra, na qual ela era a culpada pela depravação sexual (FREYRE, 2003, p.398) do jovem branco. A voz do narrador exprime essa culpa através da transformação de Jerônimo devido à "má influência" de Rita, da qual ele não seria capaz de se esquivar. Após se apaixonar pela baiana, ele deixa de trabalhar, passa a beber e "já nunca pegava na guitarra senão para procurar acertar com as modinhas que a Rita cantava. Em noites de samba era o primeiro a chegar-se e o último a ir embora" (AZEVEDO, [s/d], p. 50).

As mudanças são muitas, desde a bebida que consome até o modo de ser. A malandragem de Jerônimo é engatilhada a partir da sensualidade de Rita e do desejo sexual, trazendo vitalidade ao português: "um apego ao aqui e agora, ao corpo e aos sentidos" (MENDES, 2003, p.22).

O cavouqueiro [Jerônimo], pelo seu lado, cedendo às imposições mesológicas, enfarava a esposa, sua congênere, e queria a mulata, porque a mulata era o prazer, era a volúpia, era o fruto dourado e acre destes sertões americanos, onde a alma de Jerônimo aprendeu lascívias 
de macaco e onde seu corpo porejou o cheiro sensual dos bodes. (AZEVEDO, [s/d], p.94)

O trecho demonstra a animalização do sujeito pela degradação do impulso sexual (CANDIDO, 1993, p.113). Na afirmação "a mulata era o prazer", encontramos em evidência a erotização da mulher negra, que evoca a herança cultural da escravidão e pode ser analisada a partir da leitura de Freyre (2003). O autor faz um levantamento histórico em Casa Grande \& Senzala acerca do sistema escravista e no quarto capítulo explora a vida sexual do senhor de engenho.

Já na primeira página, Freyre explicita que há uma "predileção" do homem branco pela escrava negra, a chamada "mulata fácil": "Conhecem-se casos no Brasil não só de predileção, mas de exclusivismo: homens brancos que só gozam com negra" (FREYRE, 2003, p.343). Essa linha de raciocínio é efeito da relação perversa entre proprietário e escrava, que se revela no processo histórico e perdura na representação da personagem Rita Baiana, construída no romance de Azevedo como objeto de desejo; ela provoca ciúmes entre Firmo e Jerônimo, além da rivalidade com a portuguesa Piedade. Rita é comparada com a esposa de Jerônimo pelo erotismo que falta à outra, de modo que a baiana tem um desfecho positivo por conta da atração sexual, que traz um sentimento de satisfação pessoal a ela.

O contentamento de Rita é comparável ao sentimento de superioridade do malandro, causado pelas "rixas entre pares, que acabam se sobrepondo ao antagonismo de classes" (OTSUKA, 2007, p122); a rixa se restringe ao triunfo pessoal, mas significa também fracasso coletivo. $O$ desfecho triunfante da baiana só ocorre devido aos danos que ela causa, uma vez que sua representação não é construída positivamente na narrativa.

Diferente de Leonardo nas Memórias, Rita não pode ascender nem pelo casamento nem pela herança, portanto a solução que encontra é a relação temporária com seus amantes. A falta da estabilidade é compensada pela proteção da comunidade do cortiço, com quem troca pequenos favores e dá auxílio quando pode. Pelo que é possível inferir da narrativa, os amantes também a sustentam financeiramente, primeiro Firmo, depois Jerônimo. Ao final do romance, a personagem declara que "o amor não é obrigado" (AZEVEDO, [s/d], p. 
113), defendendo a espontaneidade e o sentimento nas relações pessoais. Por outro lado, Rita sai do cortiço com Jerônimo apenas após este indicar suas economias: "Tenho aqui sobre mim uns quinhentos mil-réis para as primeiras despesas" (AZEVEDO, [s/d], p.95), o que abre margem para questionar se há um indício de cálculo por trás da sua volubilidade e, consequentemente, de malandragem.

A construção de Rita Baiana em $O$ Cortiço parte da herança cultural escravista, da relação perversa do senhor de engenho com a escrava, do arbítrio e exploração sexual. A partir da leitura de Freyre (2003), é possível entrever o processo histórico que hiperssexualiza a mulher negra e se constrói na personagem de Aluisio Azevedo na voz do narrador. Na narrativa, o erotismo e a volubilidade também aparecem como características atribuídas à "mulata" de forma generalizada, ampliadas na figura de Rita, que se torna uma representação da "atração da terra" brasileira (CANDIDO, 1993, p.121), força natural e perigosa que corrompe o homem.

\section{Referências}

ALMEIDA, Manuel Antonio de. Memórias de um sargento de milícias. Universidade da Amazônia, núcleo de educação a distância, [s/d]. Disponível em: $<$ http://www.dominiopublico.gov.br/download/texto/ua000235.pdf> Último acesso: 02 de Março de 2020.

ARAÚJO, Homero Vizeu. Modernos e enfurecidos: O Cortiço, O Ateneu, Os Sertões e Triste Fim de Policarpo Quaresma. In Machado de Assis e arredores: Quincas Borba, Moby Dick e outras ideias fixas: ensaios. Porto Alegre: Movimento, 2011.

AZEVEDO, Aluísio. O cortiço. MINISTÉRIO DA CULTURA: Fundação Biblioteca Nacional Departamento Nacional do Livro, [s/d]. Disponível em < http://objdigital.bn.br/Acervo_Digital/Livros_eletronicos/cortico.pdf > Último acesso: 02 de Março de 2020.

BOUCINHAS, André Dutra. A escravidão nos romances do Segundo Reinado. Eixo Roda, Belo Horizonte, v. 27, n. 2, 2018, p. 105-130.

CANDIDO, Antonio. "Dialética da Malandragem". Revista do Instituto de Estudos Brasileiros, São Paulo, n. 8, 1970.

De cortiço a cortiço. In: O Discurso e a Cidade. São Paulo: Duas Cidades, 1993. p. 123-52. 
CERQUEIRA, Mirian Santos de. ENTRE FOGO E ÁGUA: o erotismo em Rita Baiana. Revista EntreLetras: Revista do Curso de Mestrado em Ensino de Língua e Literatura da UFT, n. 1, 2010.

DAMATTA, Roberto. Pedro Malasartes e os paradoxos da malandragem. In Carnavais, malandros e heróis: para uma sociologia do dilema brasileiro. Rio de Janeiro: Rocco, 1997.

FLORENTINO, Manolo; FRAGOSO, João. O arcaísmo como projeto: mercado atlântico, sociedade agrária e elite mercantil em uma economia colonial tardia. Rio de Janeiro, Editora Civilização Brasileira, 2001.

FREYRE, Gilberto. O escravo na vida sexual e de família do brasileiro. In Casa grande e senzala: Formação da família brasileira sob o regime da economia patriarcal. São Paulo: Global Editora, 48 ed., 2003.

LEITE, Guto. "Três apitos": lirismo e violência em Noel Rosa. Revista do Instituto de Estudos Brasileiros, Brasil, n. 66, p. 160-171, abr. 2017.

MENDES, Leonardo. Rita Baiana: nação e sexualidade em O cortiço. Revista Língua \& Literatura, v. 5, n. 8, 2003.

OTSUKA, Edu Teruki. Espírito rixoso: para uma reinterpretação das Memórias de um sargento de milícias. Revista do Instituto de Estudos Brasileiros, São Paulo, n. 44, fev. 2007, p. 105-124.

Conflito e interrupção: sobre um artifício narrativo em $O$ Cortiço. Terceira Margem, Rio de Janeiro, n. 21, agosto/dezembro 2009, p. 177-186. SCHWARZ, Roberto. Pressupostos, salvo engano, de Dialética da malandragem. In: Que horas são? São Paulo: Cia das Letras, 1987. p. 129. 